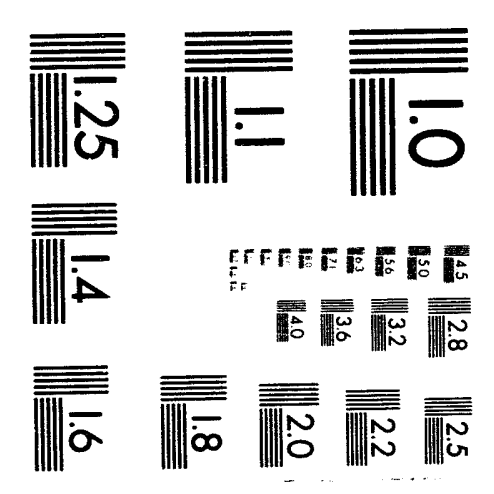



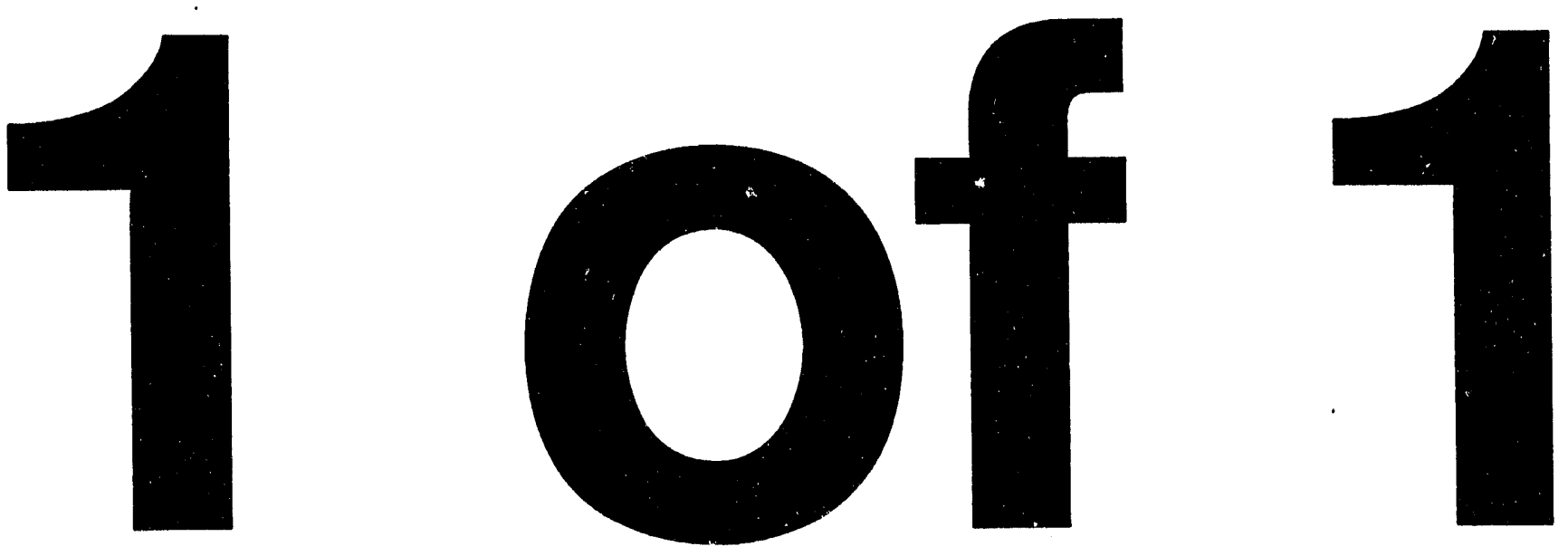
DOE/EIA-M055

\section{Propane Market Model Documentation Report}

December 1993

Energy Information Administration

Petroleum Marketing Division

Office of Oil and Gas

U.S. Department of Energy

Washington, DC 20585 


\section{Propane Market Model Documentation Report}

\section{INTRODUCTION}

\section{Purpose of the Report}

The purpose of this report is to define the objectives of the Propane Market Model (PMM), describe its basic approach, and to provide detail on model functions. This report is intended as a reference document for model analysts, users, and the general public. Documentation of the model is in accordance with EIA's legal obligation to provide adequate documentation in support of its models (Public Law 94-385, Section $57(b)(2))$.

\section{Model Summary}

The PMM performs a short-term (6-to 9-month) forecast of demand and price for consumer-grade propane in the national U.S. market; it also calculates the end-of-month stock level during the term of the forecast. Another part of the model allows for short-term demand forecasts for certain individual Petroleum Administration for Defense (PAD) districts. The model is used to analyze market behavior assumptions or shocks and to determine the effect on market price, demand, and stock level.

\section{Model Archival Citation}

The Sectoral Propane Activity Market Model (PMM) is archived on IBMcompatible micro-floppy disks and is available through the sponsoring office. The model contact is:

Charles Dale

U.S. Department of Energy

Energy Information Administration

Office of Oil and Gas

Petroleum Marketing Division

Publications and Analysis Branch

Mail Code: EI-432

Forrestal Bldg.

Room 2G-029

1000 Independence Ave., SW

Washington, DC 20585

Phone: (202) 586-1805

Fax: (202) 586-4913 


\section{Report Organization}

The remainder of this report is organized in the following manner: (1) model purpose, (2) model rationale, (3) model structure, (4) properties of mathematical solution, (5) calibration and sensitivity analysis, (6) documentation of technical detail on model data and equations, and (\%) appendices.

\section{MODEL PURPOSE}

\section{Model Objectives}

The PMM is to be used for market analysis and general forecasting purposes and was developed for presentation at the state Heating oil and Propane Program and the winter Fuels conferences as well as for the annual Propane outlook article published in the Petroleum Marketing Monthly. The model addresses very short-term, monthly U.S. market: responses at the national level and also in PAD districts I \& II. The model focuses on U.S. retail demand and market price and assesses maxket: response to alternative scenarios and/or shocks by providing very shortterm (up to 9-month) forecasts of propane demand and end-of-month stock levels, along with the market price at the national level. The model relies on the Short-Term Energy Outlook (STEO) mid-world oil price case to assist in defining a baseline (or most probable) case and then uses assumptions on different possible market disturbances to assess market: response on a monthly basis; the PMM differs from STEO because of the provision for monthly PAD district level predictions. It has been used to forecast the effect of heating degree day and crude price changes on propane product supplied and market price. The PMM also provides a framework to calculate stock levels from the forecasted demand and prict. variables.

\section{Model Input/Output}

The PMM uses both DOE and non-DOE data input sources. The non pof came from two sources. Data Resources, Inc. (DRI) databases pi ine values from the Bureau of Labor Statistics, for general macroeconomi: variables (including the producer price index). The National oceari. sud Atmospheric Administration was the source for heating degree di. information. The DOE historical data for crude oil prices, refince. variables, propane demand, stock levels, and retail price came frum publications: the Petroleum Marketing Annual/Monthly (various issus:) the petroleum Supply Annual/Monthly (various issues), the $1 \mathrm{ef}$ Petroleum Status Report (various issues) and the winter Fuels RuLC! (various issues). Forecasts for future values of the indeperite: variables used in the PMM came from EIA's 3 rd quarter Short-Telly. 
Integrated Forecasting System (Energy Information Administration, 1993) and Petroleum Marketing Division analysis of current market trends.

output from the PMM includes very short-term monthly forecasts of national U.S. demand, market price, and stock levels of consumer-grade propane, and also propane market demand in certain PAD districts.

\section{Relationship to Other Models}

The PMM does not directly interface with other models. However, the model directly utilizes forecasts of certain macroeconomic and energy price variables from the Short-Term Integrated Forecasting System (STIFS) as inputs.

\section{MODEL OVERVIEW AND RATIONALE}

\section{Fundamental Assumptions}

The PMM is to be used to judge the effect of shocks or alternative behavior assumptions on the demand, price, and end-of-month stock level for consumer-grade propane in the national economy. The theoretical basis for the model is the standard demand-supply approach used to determine the market effects of shifting demand and supply curves on a single product in an isolated market; it implicitly makes the assumption that all economic entities exhibit profit-maximizing behavior. The model indirectly allows for feedback effects between price and demand over a monthly time frame. Although the model functions at a monthly frequency, conclusions are normally drawn from the model on a quarterly or semi.annual basis. The PMM uses recent historical market behavior as a pattern for predisting near-term future market responses.

The PMM is concerned with very short-term (i.e., 6- to 9-month) projections into the future. In order to make the analysis more tractable, a number of simplifying assumptions were made concerning the behavior of the propane market; these include:

- Constant relative size of vehicle fleet using alternative fuels. It is assumed that there is no sudden demand surge due to the use of propane as an alternative vehicle fuel.

- The consumer propane market is isolated from disturbances to other petroleum product markets. It is assumed that any significant interaction between the propane market and other product markets would not occur within the timeframe of the forecast.

- Constant delivery infrastructure. It is assumed that there will be no significant changes in the consumer-grade propane distribution infrastructure during the duration of the forecast. 
- The relative proportion of homes using propane for heating purposes remains constant. Additionally, furnace efficiency is assumed to be constant over the timeframe of the model projections.

- No dramatic changes in the macroeconomic or natural conditions. It is also assumed that the relative pricing structure of petrochemical inputs does not radically change.

- No changes in refinery economic conditions. All scenarios were conducted under the assumption that refinery and production conditions do not radically change during the duration of the forecast. Net imports are also assumed to be exogenously determined.

The model assumes that the data series identified as Propane/Propylene in the Petroleum Supply Monthly is entirely sold as consumer-grade propane and that the price of the product reflects that to the end user (or residential customer) in a retail market. The model also assumes that the data series "Propane (Consumer-grade), Sales to End Users" as published in the petroleum Marketing Monthly does not measure the same market as the "Residential Propane Prices" reported in the winter Fuels Report.

The PMM allows market players to make pricing decisions based on historical price, demand, and stock patterns. The model assumes that market players make decisions on a monthly basis; although this may be somewhat of a long reference time frame, any analysis utilizing a more rapid decisionmaking process would be hampered by the lack of data availability at higher frequencies.

\section{Alternative Approaches}

The PMM is a time series model typical of a form used for the estimation of propane demand (see, for example, Short-Term Integrated Forevasting System, 1993). Cross-sectional models of end user purchasing behavior were not considered because of the need to forecast market adjustments to possible shocks for longer than a single time period. The STIFS model was not used because of the desire to model the residential or end-use propane market as being distinct from the liquefied petroleum gas market; additionally, the retail price utilized by the STIFS model is at best an imperfect measure of the actual residential price for commercial grade propane.

\section{MODEL STRUCTURE}

\section{Flow Diagram of National Model}


PROPANE MARKET MODEL FLOW DIAGRAM

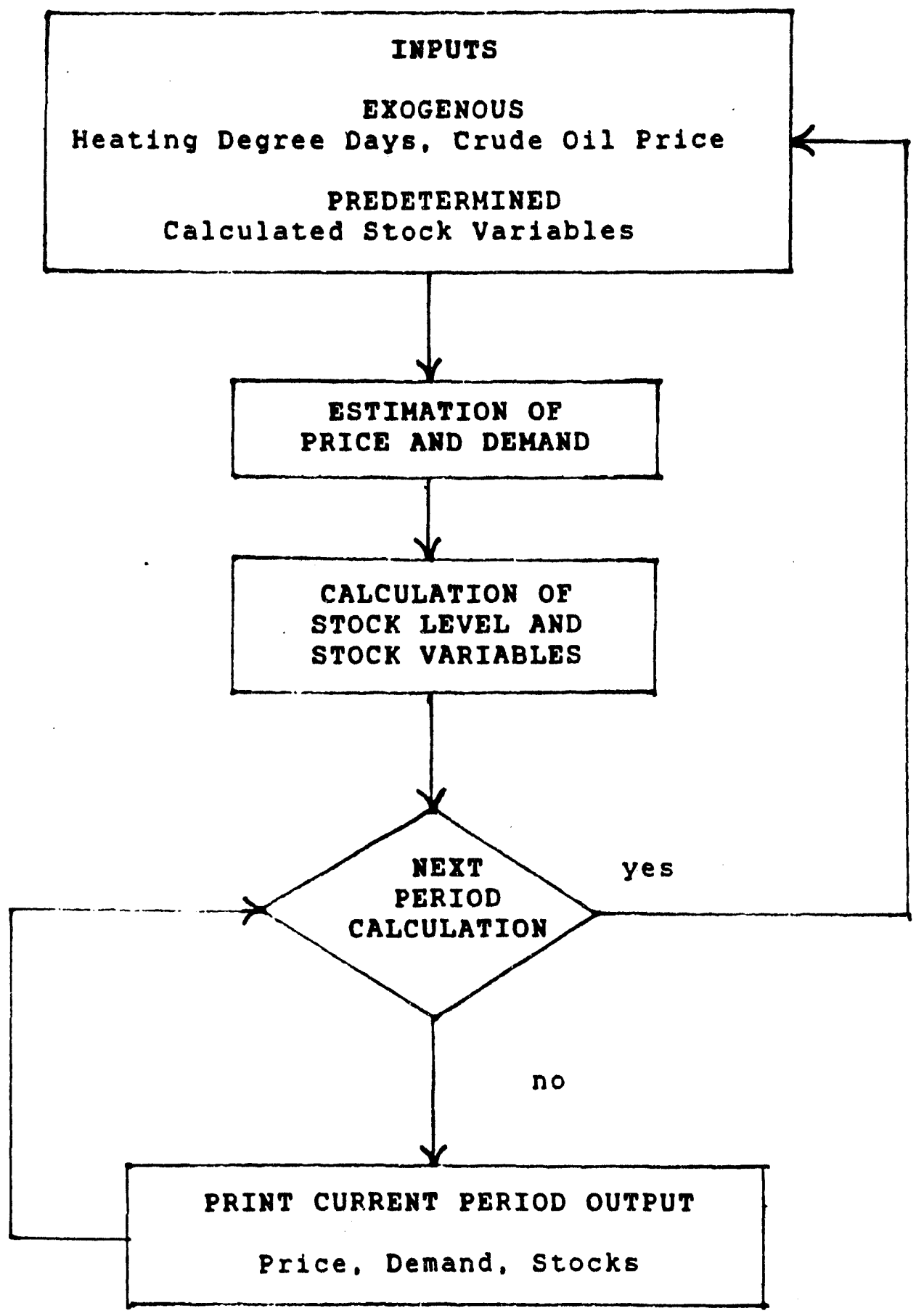

Energy Information Administration/Petroleum Marketing Division Propane Market Model Documentation Report 
Solution of the PMM proceeds in a straight forward manner. The input variables are used as exogenous and predetermined variables for the independent estimation of demand and price. The model then algebraically calculates the projected stock level and other stock related variables used as inputs. The current period solution is printed and the model proceeds, if necessary, to the estimation for the next period.

\section{List of Computations and Equations for National Model}

The equation used by the model for the estimation of end-user price is of the form:

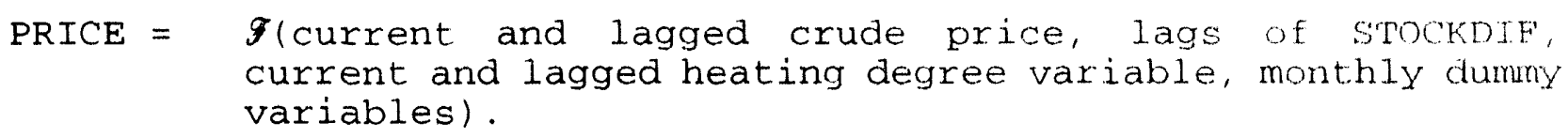

The actual estimated price equation is:

$$
\begin{aligned}
& \text { PRICE }_{\mathrm{t}}=\boldsymbol{\alpha}_{0}+\boldsymbol{\alpha}_{12}{ }^{*} \mathrm{CRUDE}_{\mathrm{t}}+\boldsymbol{\alpha}_{13}{ }^{*} \mathrm{CRUDE}_{\mathrm{t}-1}+\boldsymbol{\alpha}_{14}{ } \text { STOCKDIF }_{\mathrm{t}-1} \\
& +\boldsymbol{\alpha}_{15}{ }^{\text {STOCKDIF }} \mathrm{t}-2+\boldsymbol{\alpha}_{16}{ }^{*} \text { HDDSPSQ }_{t}+\boldsymbol{\alpha}_{17}{ }^{\star} \text { HDDSPSQ }_{\mathrm{t}-1} \\
& +\sum_{i=1}^{11} \boldsymbol{\alpha}_{i} \star D_{M M M Y}
\end{aligned}
$$

The equation used to calculate the residential price is:

$$
\text { RESPRICE }=\mathrm{PRICE}_{\mathrm{t}} \mathrm{PPI}_{\mathrm{t}}+\gamma_{\mathrm{t}}
$$

The equation used to calculate the end-user price is:

$$
\text { RETPRICE } E_{t}=P R E_{t}{ }^{*} P P I_{t}
$$

The equation used by the model for the estimation of demand (product supplied) is of the form:

$$
\begin{aligned}
\text { DEMAND = } & \text { F(lagged STOCKDIF, current heating degree days, } \\
& \text { agricultural crop drying dummy variables, monthiy dunny } \\
& \text { variables). }
\end{aligned}
$$

The actual estimated demand equation is:

$$
\begin{aligned}
& \text { DEMAND }_{\mathrm{t}}=\boldsymbol{\beta}_{0}+\boldsymbol{\beta}_{12}{ }^{\star} \operatorname{STOCKDIF}_{\mathrm{t}-2}+\boldsymbol{\beta}_{13}{ }^{\star} \mathrm{HDD}_{\mathrm{t}}+\sum_{1=1}^{11} \boldsymbol{\beta}_{\mathrm{i}} \star \mathrm{DUMMY}_{\mathrm{i}} \\
& +\boldsymbol{\beta}_{15}{ }^{\star} \text { DONOV92 }+\boldsymbol{\beta}_{16}{ }^{\star} \text { DODEC92 }
\end{aligned}
$$


where PRICE is the average (consumer-grade) propane refinery price to end-users deflated by the Producer Price Index, with outliers smoothed if necessary.

RESPRICE is the residential price of consumer-grade propane.

PPI is the producer price index.

RETPRICE is the average (consumer-grade) propane refinery price to end-users.

HDD is the mean deviation from the national norm of heating degree days ${ }^{1}$.

$\operatorname{HDDSPSQ}=\left\{\begin{array}{l}\mathrm{HDD}^{*} * 2 \text { if } \mathrm{HDD} \geq 0 \\ 0 \text { if } \mathrm{HDD}<0\end{array}\right.$

CRUDE is the average imported refiners acquisition cost of crude oil deflated by the Producer Price Index.

STOCKDIF is the deviation of the current stock level from the average of the previous 3 years.

DEMAND is the propane product supplied.

$\boldsymbol{\gamma}$ is an additive adjustment used to compensate for the difference between the end-user price and residential price. By definition:

$$
\gamma_{i}=\left\{\begin{array}{rrr}
\text { MEAN (RESPRICE } & \left.- \text { PRICE }_{i}\right) & \forall \text { years, if } \\
i=O C T, \text { NOV, DEC, JAN, FEB, MAR }
\end{array}\right.
$$

DUMMY $_{i}$ are monthly dummy variables.

D0NOV92 are dummy variables for November, 1992 and December, DODEC92 1992, respectively.

$t$

is the subscript variable for monthly time series observations.

The inputs to the above equations are exogenous (i.e. STEO estimated) or previously calculated values for the variables. Direct output from these equations consist of one month ahead forecasts of PRICE, RESPRICE and DEMAND for total consumer-grade propane. The determination of the one

\footnotetext{
${ }^{1} \mathrm{HDD}_{\mathrm{t}}=\left(\mathrm{HDDA}_{\mathrm{t}}-\mathrm{HDDN}_{\mathrm{t}}\right) / \mathrm{DAYS}$, where $\mathrm{HDDA}_{\mathrm{t}}$ is the actual population weighted heating degree days for time period $t$ and $\mathrm{HDDN}_{\mathrm{t}}$ is the estimated 30 year average (1951 - 1980 basis) for each period.
} 
month ahead stock level from the forecasted level of demand is calculat by the following formulas:

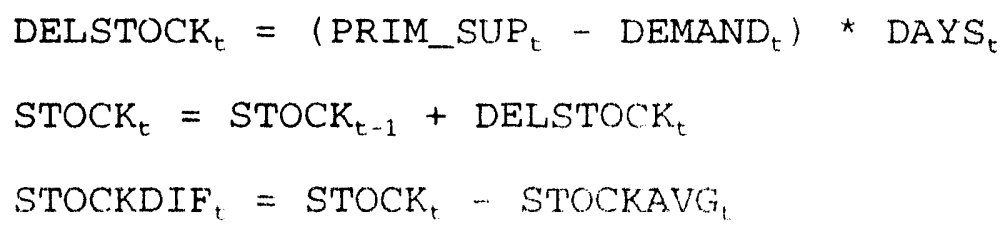

where

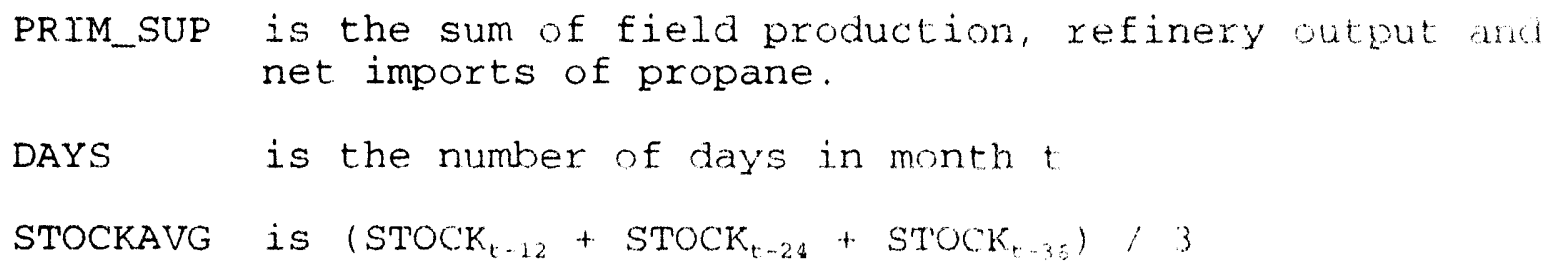

Flow Diagram of PAD District Models 
PROPANE PAD DISTRICT I MODEL FLOH DIAGRAM

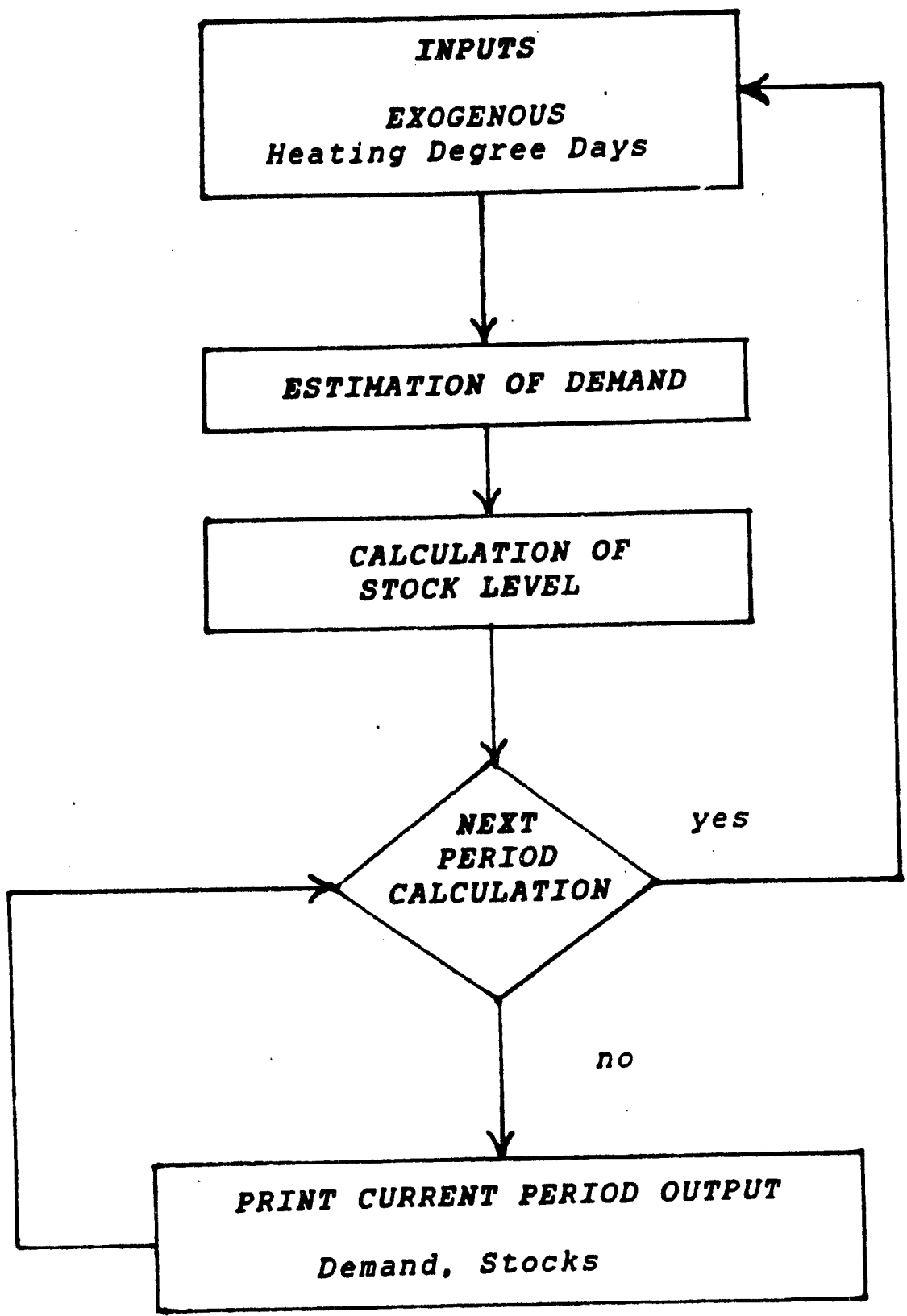


PROPANE PAD DISTRICT II MODEL FLOW DIAGRAM

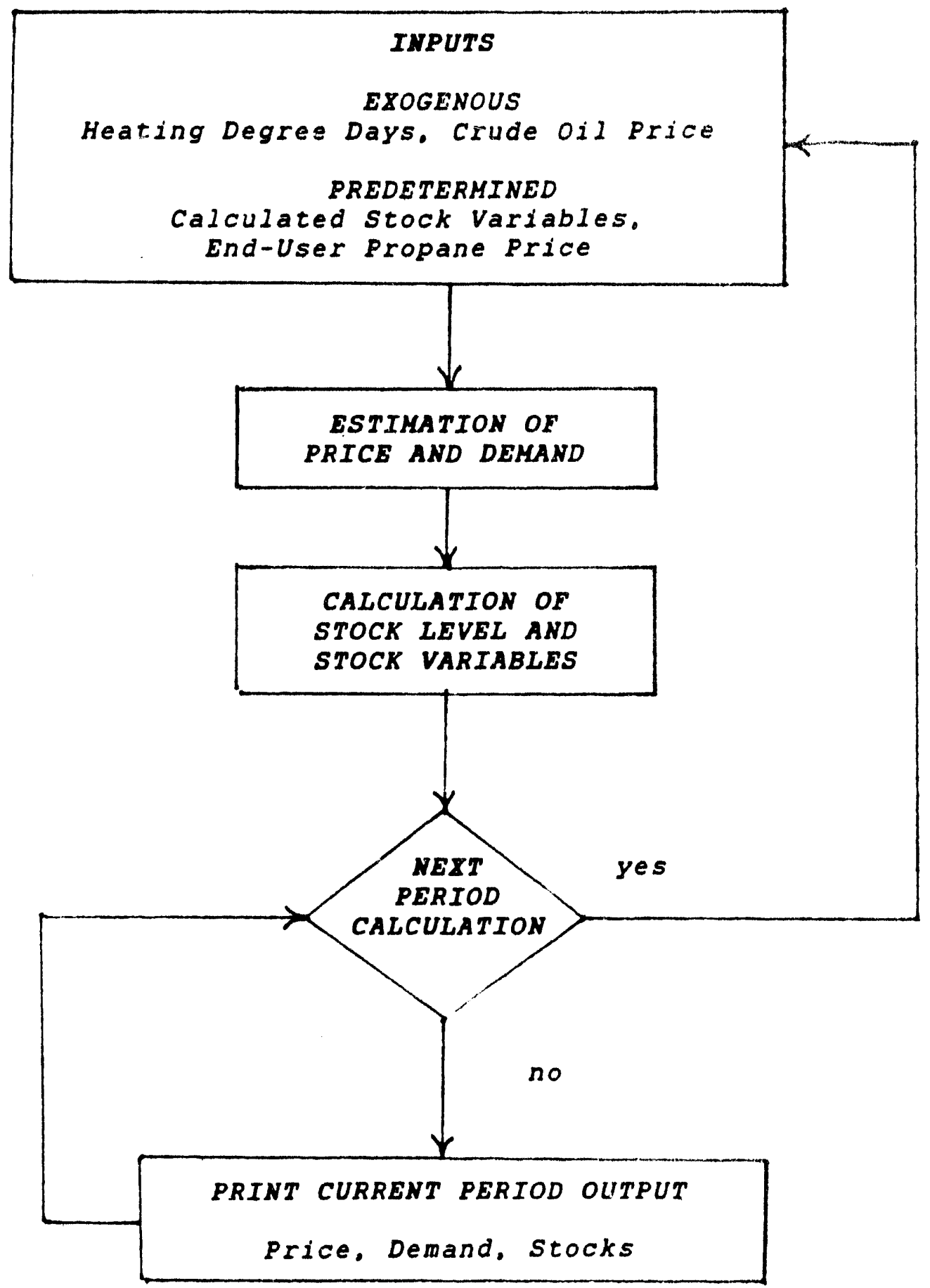
Propane Market Model Documentation Report 
The equation used by the model for the estimaliion of demand in PAD district $I$ is of the form:

DEMAND = $g$ (current heating degree days, agricultural crop drying dummy variables, monthly dummy variables).

The actual estimated demand equation is:

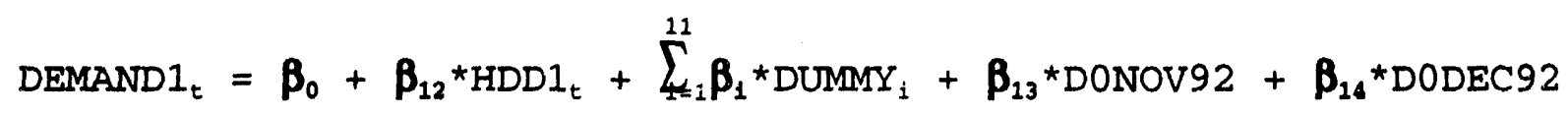

The equation used by the model for the estimation of end-user price in PAD district II is of the form:

$$
\begin{aligned}
& \text { PRICE = } \begin{array}{l}
\text { F(crude price, lagged stock variable, lagged heating } \\
\text { degree variable, } 12 \text {-month lag on price, monthly dummy } \\
\text { variables). }
\end{array}
\end{aligned}
$$

The actual estimated price equation is:

12

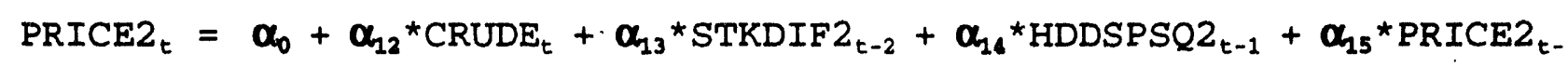

$$
+\sum_{i=1}^{11} \alpha_{i} * \text { DUMMY }_{1}
$$

The equation used by the model for the estimation of demand in PAD district II is of the form:

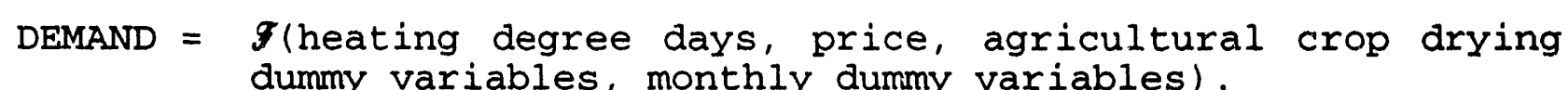

The actual estimated demand equation is:

$$
\begin{aligned}
& \text { DEMAND2 } t_{t}=\beta_{0}+\beta_{12}{ }^{*} \text {HDD2}_{t}+\beta_{13} * \text { PRICE2 } t+\sum_{i=1}^{11} \beta_{i} * \text { DUMMY } i \\
& +\beta_{14} \star \text { DONOV92 }+\beta_{15} \star \text { DODEC92 }
\end{aligned}
$$

where PRICE2 is the average (consumer-grade) propane refinery price to end-users in PAD district II deflated by the Producer Price Index. 
HDD1 is the mean deviation from normal heating degree days in PAD district 1.

HDD2 is the mean deviation from normal heating degree days in PAD district 2 .

HDDSPSQ2 $=\left\{\begin{array}{l}\mathrm{HDD} 2 * \star 2 \text { if } \mathrm{HDD} 2 \geq 0 \\ 0 \text { if } \mathrm{HDD} 2<0\end{array}\right.$

STKDIF2 is the deviation of the current stock level in PAD district 2 from the average of the previous 3 years.

DEMAND1 is the propane product supplied in PAD district 1.

DEMAND2 is the propane product supplied in PAD district 2 .

where the remaining variables having been previously defined.

The inputs to the above equations are exogenous (i.e., STEO estimated) or previously calculated values for the variables. Direct output from these equations consists of 1-month-ahead forecasts of DEMAND (and PRICE) for consumer-grade propane in the individual PAD districts. The determination of the 1-month-ahead stock level from the forecasted level of demand is calculated by using the following formulas:

for PAD district I,

$$
\begin{aligned}
& \text { DELSTK } 1_{t}=\left(\text { PRIMSUP } 1_{t}-\text { DEMAND } 1_{t}\right) \star D A Y S \\
& \text { STOCK } 1_{t}=S T O C K 1_{t-1}+\text { DELSTK1 } \\
& \text { STKDIF } 1_{t}=S T O C K 1_{t}-\text { STKAVG } 1_{t}
\end{aligned}
$$

and for PAD district II,

$$
\begin{aligned}
& \text { DELSTK2 } 2_{t}=\left(\text { PRIMSUP2 }_{t}-\text { DEMAND2 }_{t}\right) \star \text { DAYS }_{t} \\
& \text { STOCK2 }{ }_{t}=\text { STOCK2 } 2_{t-1}+\text { DELSTK2 }{ }_{t} \\
& \operatorname{STKDIF} 2_{t}=S T O C K 2_{t}-\operatorname{STKAVG} 2_{t}
\end{aligned}
$$

where PRIMSUPx is the sum of field production, refinery output, net imports and net receipts of propane for PAD district I (when $\mathrm{x}=1$ ) and PAD district II (when $\mathrm{x}=2$ ).

STKAVGX is calculated by the following formula for PAD district $I$ (when $x=1$ ) and PAD district II (when $\mathrm{x}=2$ ) :

$$
\text { STKAVGX }_{t}=\left(\text { STOCKx }_{t-12}+\operatorname{STOCKx}_{t-24}+\operatorname{STOCK} x_{t-36}\right) / 3
$$




\section{Theoretical Considerations}

The U.S. model is a standard demand-supply set of equations with no contemporaneous direct dependence between the demand and price equations. Any possible problem of simultaneous equations bias was addressed by formulating the model as a set of equations with no direct dependency among the dependent variables. Both dependent variables, viz. price and demand, are independently determined only by exogenous and predetermined variables. The predetermined stock variable is determined directly from the demand equation and from exogenous refinery and economic variables; in its lagged form, the stock variable implicitly acts (with a lag) as a price variable in the demand regression equation. There is indirect feedback from the demand equation to the price equation through the lagged stock variable; the lack of a direct feedback from demand to price implies that a disturbance to the demand equation will not greatly affect the price equation. Thus, there is probably no contemporaneous correlation between the demand equation and price, so that ordinary Least Square (OLS) estimate is unbiased ( $P$. Kennedy, 1985).

The demand equation for PAD district II includes the current price as an explanatory variable; thus, simultaneous equation bias will exist. However, the size of any contemporaneous correlation is expected to be small in the inelastic demand range in which the model is designed to wor's and because heating degree days capture a very large portion of the fluctuation in demand.

Certain a priori restrictions were placed on the domain of a number of variables. These include:

- The lag-one autocorrelation parameter of the model has a domain between -1 and +1

- The elasticity of demand is between 0 and -1 ; the elasticity of supply is greater than zero

- The price, demand, and stock level are finite and greater than zero.

\section{Subject-Matter Considerations}

The original purpose of the PMM was to model the residential (as being different from the retail) consumer-grade propane market at the national level, and to a more limited extent, at certain PAD district levels. Data limitations required expanding the focus of the analysis so as to model the retail market as opposed to the residential market for propane. The definitions used in this document are: 
END-USER PRICE:

This is the average price for the sale of consumer-grade propane by refiners to end-users as is reported in the petroleum Marketing Monthly. These monthly data include sales to industrial users and resellers to the residential market; the data are available at the national level for all months and at the PAD district level for most months.

RESIDENTIAL PRICE: This is the average price for the sale of consumer-grade propane directly to residential customers as is reported in the winter Fuels Report. The data are available for a 6-month period beginning in october and include values for PAD districts 1 through 3 and an average.

From the above distinction between end-user and residential prices, a number of observations can be easily inferred:

- The residential price is higher than the retail price.

- The residential price is a more reliable indicator of the price paid by actual residential consumers. This is the value of most interest to State Energy offices and congressional staffs.

- The average (end-user) price quoted by individual refiners varies by a factor of 3 (eg. 20 to 60 cents per galion) depending on the principal customer of the refiner.

The PMM assumes that market reactions are based on recent historical patterns. While the annual incorporation of current data with historical trends may affect the PMM's responsiveness, minor structural changes in the market can be accommodated with modifications to the equations. The domain of the input variables is assumed to be that of the recent historical time series for the individual variables.

\section{CALIBRATION AND SENSITIVITY ANALYSIS}

\section{Results of Calibration}

Calibration of the model was performed using a comparison of the forecasts for demand, retail price, and end-of-month stock level forecasted by the PMM with the STIFS values for the period June, 1993, through March, 1994. The following three tables illustrate the comparison values. It should be noted that the PMM end-of-month stock 
values for the first 2 -months (i.e., June and July) reported in the tables were estimated from actual data ${ }^{2}$.

PROPANE OUTLOOK: DEMAND

Comparison of STEO and PMM Forecasts

\begin{tabular}{||c|c|c||}
\hline DATE & $\begin{array}{c}\text { STEO } \\
(\text { MMbbl/d })\end{array}$ & $\begin{array}{c}\text { PMM } \\
(\text { MMbbl/d })\end{array}$ \\
\hline Jun-93 & 754 & 720 \\
\hline Jul-93 & 775 & 793 \\
\hline Aug-93 & 818 & 855 \\
\hline Sep-93 & 899 & 945 \\
\hline Oct-93 & 1005 & 1076 \\
\hline Nov-93 & 1037 & 1098 \\
\hline Dec-93 & 1159 & 1233 \\
\hline Jan-94 & 1303 & 1353 \\
\hline Feb-94 & 1182 & 1282 \\
\hline Mar-94 & 1037 & 1106 \\
\hline
\end{tabular}

${ }^{2}$ The tabulated values were estimated from a linear interpolation of weekly data published in the Weekly Petroleum Status Report, DOE/EIA-0208, various issues. 
PROPANE OUTLOOK: STOCKS

Comparison of STEO and PMM Forecasts

\begin{tabular}{||c|c|c||}
\hline DATE & $\begin{array}{c}\text { STEO } \\
\text { (MMbb1) }\end{array}$ & $\begin{array}{c}\text { PMM } \\
(\text { MMbbl })\end{array}$ \\
\hline Jun-93 & 46.652 & 44.900 \\
\hline Jul-93 & 52.705 & 51.700 \\
\hline Aug-93 & 57.425 & 57.140 \\
\hline Sep-93 & 58.886 & 59.697 \\
\hline Oct-93 & 56.391 & 58.570 \\
\hline Nov-93 & 50.951 & 56.674 \\
\hline Dec-93 & 44.922 & 50.539 \\
\hline Jan-94 & 35.818 & 40.682 \\
\hline Feb-94 & 30.575 & 33.916 \\
\hline Mar-94 & 30.338 & 31.876 \\
\hline
\end{tabular}

PROPANE OUTLOOK: END-USER PRICE

Comparison of STEO and PMM Forecasts

\begin{tabular}{||c|c|c|}
\hline DATE & $\begin{array}{c}\text { STEO } \\
\text { (cents/gal) }\end{array}$ & $\begin{array}{c}\text { PMM } \\
\text { (cents/gal) }\end{array}$ \\
\hline \hline Jun-93 & 65.4 & 61.2 \\
\hline Jul-93 & 64.0 & 61.5 \\
\hline Aug-93 & 65.1 & 63.7 \\
\hline Sep-93 & 67.4 & 63.2 \\
\hline Oct-93 & 68.2 & 62.3 \\
\hline Nov-93 & 70.6 & 66.5 \\
\hline Dec-93 & 74.0 & 73.5 \\
\hline Jan-94 & 77.4 & 75.2 \\
\hline Feb-94 & 76.5 & 74.7 \\
\hline Mar-94 & 72.8 & 71.0 \\
\hline
\end{tabular}


Another calibration was done by using the PMM to perform a dynamic ex post forecast of propane end-user price and demand for the first two quarters in calendar year 1993. The results are shown in the next two tables, along with the actual values and the STIFS projections for the same time period ${ }^{3}$. It can be seen that the accuracy of the PMM values compare favorably to those generated by STIFS.

\section{U.S. NATIONAL PROPANE EX POST FORECAST: END-USER PRICE Comparison of Model Predictions with Actual Values (Cents per Gallon)}

\begin{tabular}{|c|c|c|c|c|}
\hline DATE & SERIES & ACTUAL & PMM & STEO \\
\hline $\begin{array}{c}\text { 1st } \\
\text { Quarter, } \\
1993\end{array}$ & Value & 74.7 & 71.6 & 71.4 \\
\hline & $\begin{array}{c}\text { Deviation } \\
\text { from Actual }\end{array}$ & & -3.1 & -3.3 \\
\hline $\begin{array}{c}2 \text { 2nd } \\
\text { Quarter, } \\
1993\end{array}$ & Value & 67.0 & 64.6 & 64.6 \\
\hline & $\begin{array}{c}\text { Deviation } \\
\text { from Actual }\end{array}$ & & -2.4 & -2.4 \\
\hline
\end{tabular}

${ }^{3}$ The STIFS values were taken from a computer run generated on 30MAR93, and include some published values for the first quarter. 
U.S. NATIONAL PROPANE EX POST FORECAST: DEMAND

Comparison of Model Predictions with Actual Values

(Thousands Barrels per Day)

\begin{tabular}{|c|c|c|c|c|}
\hline DATE & SERIES & ACTUAL & PMM & STEO \\
\hline \multirow[t]{2}{*}{$\begin{array}{c}1 \text { st } \\
\text { Quarter, } \\
1993\end{array}$} & Value & 1200 & 1213 & 1231 \\
\hline & $\begin{array}{l}\text { Deviation } \\
\text { from Actual }\end{array}$ & & +13 & +31 \\
\hline \multirow[t]{2}{*}{$\begin{array}{c}2 \text { nd } \\
\text { Quarter } \\
1993\end{array}$} & Value & 767 & 755 & 866 \\
\hline & $\begin{array}{l}\text { Deviation } \\
\text { from Actual }\end{array}$ & & -12 & +99 \\
\hline
\end{tabular}

Another calibration was done by using the PMM(PADD1) to perform a dynamic ex post forecast of propane demand in PAD district I for the first two quarters in calendar year 1993. The results are shown in the next table. (Values from the STIFS model are not available at the PAD district level.)

PAD DISTRICT 1 PROPANE EX POST FORECAST: DEMAND Comparison of Model Predictions with Actual Values (Thousands Barrels per Day)

\begin{tabular}{||c|c|c|c||}
\hline $\begin{array}{c}\text { DATE } \\
\begin{array}{c}\text { 1st } \\
1993\end{array}\end{array}$ & SERIES & ACTUAL & PMM \\
\hline & Value & 225 & 228 \\
\hline $\begin{array}{c}\text { Deviation } \\
\text { 2nom Actual } \\
\text { Quarter, } \\
\text { 1993 }\end{array}$ & Value & 116 & 116 \\
\hline \multicolumn{1}{|c|}{} & $\begin{array}{c}\text { Deviation } \\
\text { from Actual }\end{array}$ & & 0 \\
\hline
\end{tabular}


Another calibration was done by using the PMM(PADD2) to perform a dynamic ex post forecast of propane demand and end-user price in PAD district II

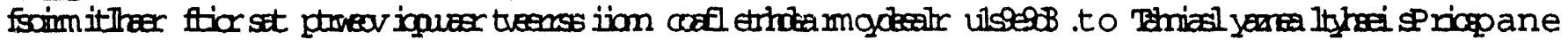
Market in PAD district 2 during the 1992-93 heating season (see Burdette, et al., 1993). The results are shown in the next two tables. (Values from the STIFS model are not available at the PAD district level.)

PAD DISTRICT II PROPANE EX POST FORECAST: END-USER PRICE Comparison of Model Predictions with Actual Values (Cents per Gallon)

\begin{tabular}{||c|c|c|c|}
\hline DATE & SERIES & ACTUAL & PMM \\
\hline $\begin{array}{c}\text { 1st } \\
\text { 1993 }\end{array}$ & Value & 82.8 & 78.5 \\
\hline & $\begin{array}{c}\text { Deviation } \\
\text { from Actual }\end{array}$ & & -4.3 \\
\hline $\begin{array}{c}\text { 2nd } \\
\text { Quarter, } \\
\text { 1993 }\end{array}$ & Value & 79.9 & 71.5 \\
\hline \multicolumn{1}{|c|}{$\begin{array}{c}\text { Deviation } \\
\text { from Actual }\end{array}$} & & -8.4 \\
\hline
\end{tabular}

PAD DISTRICT II PROPANE EX POST FORECAST: DEMAND

Comparison of Model Predictions with Actual Values (Thousands Barrels per Day)

\begin{tabular}{||c|c|c|c|}
\hline $\begin{array}{c}\text { DATE } \\
\begin{array}{c}\text { 1st } \\
\text { 1993 }\end{array}\end{array}$ & SERIES & ACTUAL & PMM \\
\hline & $\begin{array}{c}\text { Deviation } \\
\text { from Actual }\end{array}$ & 370 & 404 \\
\hline $\begin{array}{c}\text { 2nd } \\
\text { Quarter, } \\
1993\end{array}$ & Value & 193 & 184 \\
\hline & $\begin{array}{c}\text { Deviation } \\
\text { Erom Actual }\end{array}$ & & -94 \\
\hline
\end{tabular}


The PAD district 2 retail propane market underwent a severe disruption during the 1992-93 heating season due to unseasonable cold weather and late crop drying during the 4 th quarter of 1992 . The effects of this market stress were still being felt during the first part of the following year (see Burdette, et al., 1993) for a more extensive discussion of the causes and effects of this market disturbance.) One of the effects that the PMM(PADD2) was not able to fully capture was the large run-up of end-user prices. In order to verify the adequacy of the model in more normal market circumstances, another dynamic ex post simulation of the model was done for the first three quarters in the 1993 calendar year. Even though the regression model was based on data time series of only 36 months, the results, as presented in the next two tables, show deviations from actual values of less than 10 percent.

PAD DISTRICT II PROPANE EX POST FORECAST: END-USER PRICE Comparison of Model predictions with Actual Values (Cents per Gallon)

\begin{tabular}{||c|c|c|c||}
\hline $\begin{array}{c}\text { DATE } \\
\begin{array}{c}\text { 1st } \\
\text { 1992 }\end{array}\end{array}$ & SERIES & ACTUAL & PMM \\
\hline & Value & 72.5 & 75.3 \\
\hline $\begin{array}{c}\text { 2nd } \\
\text { Quarter, } \\
\text { 1992 }\end{array}$ & Veviation Actual \\
\hline & $\begin{array}{c}\text { Deviation } \\
\text { from Actual }\end{array}$ & 67.4 & +2.8 \\
\hline $\begin{array}{c}\text { 3rd } \\
\text { Quarter, } \\
\text { 1992 }\end{array}$ & $\begin{array}{c}\text { Value } \\
\text { Value }\end{array}$ & 64.6 & +2.7 \\
\hline \multicolumn{1}{|c|}{$\begin{array}{c}\text { Deviation } \\
\text { from Actual }\end{array}$} & & +5.1 \\
\hline
\end{tabular}


PAD DISTRICT II PROPANE EX POST FORECAST: DEMAND

Comparison of Model Predictions with Actual Values

(Thousands Barrels per Day)

\begin{tabular}{||c|c|c|c||}
\hline $\begin{array}{c}\text { DATE } \\
\text { Quarter, } \\
1992\end{array}$ & SERIES & ACTUAL & PMM \\
\hline & $\begin{array}{c}\text { Deviation } \\
\text { from Actual }\end{array}$ & 341 & 363 \\
\hline $\begin{array}{c}\text { 2nd } \\
\text { Quarter, } \\
1992\end{array}$ & $\begin{array}{c}\text { Value } \\
\text { Value }\end{array}$ & 179 & +22 \\
\hline $\begin{array}{c}\text { 3rd } \\
\text { Quarter, } \\
1992\end{array}$ & $\begin{array}{c}\text { Deviation } \\
\text { from Actual }\end{array}$ & 237 & 232 \\
\hline & $\begin{array}{c}\text { Deviation } \\
\text { from Actual }\end{array}$ & & -15 \\
\hline
\end{tabular}

\section{Model Runs to Test Concordance with Intuition}

The PMM underwent two tests to determine its correspondence with intuition and economic theory. This test was performed by increasing the severity of a prolonged cold snap during the heating season and was done in two parts: (1) the cold Heating Season case, which increases the total mean heating degree days during the october through March season by 10 percent over the normal amount and (2) the cold winter case, which takes the same number of increased mean heating degree days and apportions this amount just over the winter months (i.e., January through March). Since one of the principal uses of consumer-grade propane is for residential and industrial heating, the results of this test should show that during the period of colder temperatures, demand for propane will increase over and above that in the base case. The increased demand would create a larger demand/supply imbalance, thus putting additional upward pressure on prices, and would also result in larger stock drawdowns. This expected pattern of market behavior emulates that described in the EIA service report entitled "An Analysis of Heating Fuel Market Behavior, 1989-90", which provides an ex post analysis of a severe 1-month cold snap. 
The following tables show the PMM's behavior under these scenarios and demonstrates the models concordance with intuition. The model predicts that both the demand and retail price of distillate will rise, beginning in the first month of the appearance of the cold snap.

PROPANE SCENARIOS: DEMAND

Impact of Alternative Scenario Assumptions

(Thousand Barrels per Day)

\begin{tabular}{||c|c|c|c||}
\hline DATE & BASE CASE & $\begin{array}{c}\text { COLD HEATING } \\
\text { SEASON }\end{array}$ & $\begin{array}{c}\text { COLD } \\
\text { WINTER }\end{array}$ \\
\hline Aug-93 & 855 & 855 & 854 \\
\hline Sep-93 & 945 & 945 & 945 \\
\hline Oct-93 & 1076 & 1102 & 1076 \\
\hline Nov-93 & 1098 & 1153 & 1098 \\
\hline Dec-93 & 1233 & 1310 & 1233 \\
\hline Jan-94 & 1353 & 1433 & 1510 \\
\hline Feb-94 & 1282 & 1339 & 1422 \\
\hline Mar-94 & 1106 & 1129 & 1185 \\
\hline
\end{tabular}

PROPANE SCENARIOS: END-USER PRICE

Impact of Alternative Scenario Assumptions (Cents per Galion)

\begin{tabular}{|c|c|c|c|}
\hline DATE & BASE CASE & $\begin{array}{c}\text { COLD HEATING } \\
\text { SEASON }\end{array}$ & $\begin{array}{c}\text { COLD } \\
\text { WINTER }\end{array}$ \\
\hline \hline Aug-93 & 63.7 & 63.7 & 63.7 \\
\hline Sep-93 & 63.2 & 63.2 & 63.2 \\
\hline Oct-93 & 62.3 & 62.4 & 62.3 \\
\hline Nov-93 & 66.5 & 66.7 & 66.5 \\
\hline Dec-93 & 73.5 & 74.7 & 73.5 \\
\hline Jan-94 & 75.2 & 77.9 & 75.9 \\
\hline Feb-94 & 74.7 & 78.7 & 80.4 \\
\hline Mar-94 & 71.0 & 75.6 & 77.5 \\
\hline
\end{tabular}


PROPANE SCENARIOS: STOCK LEVEL

Impact of Alternative Scenario Assumptions

(Millions of Barrels)

\begin{tabular}{||c|c|c|c||}
\hline DATE & BASE CASE & $\begin{array}{c}\text { COLD HEATING } \\
\text { SEASON }\end{array}$ & $\begin{array}{c}\text { COLD } \\
\text { WINTER }\end{array}$ \\
\hline Aug-93 & 57.140 & 57.140 & 57.140 \\
\hline Sep-93 & 59.697 & 59.697 & 59.697 \\
\hline Oct-93 & 58.570 & 57.765 & 58.570 \\
\hline Nov-93 & 56.674 & 54.212 & 56.674 \\
\hline Dec-93 & 50.539 & 45.681 & 50.539 \\
\hline Jan-94 & 40.682 & 33.346 & 35.826 \\
\hline Feb-94 & 33.916 & 24.970 & 25.119 \\
\hline Mar-94 & 31.876 & 22.221 & 20.935 \\
\hline
\end{tabular}

\section{DOCUMENTATION OF TECHNICAL DETAIL ON MODEL DATA AND EQUATIONS}

\section{Validation of Input Data}

Input variables which the PMM has in common with the STIFS were used with identical values.

Non-DOE Input Sources:

Data Resources, Inc. (DRI) database, data from Bureau of Labor Statistics

- Producer price index data

U.S. Department of Commerce, National Oceanographic and Atmospheric Administration, Data Source DRD $964 \mathrm{X}$

- Actual and normal statewide monthly heating degree day values. 


\section{Forms and Publications:}

Energy Information Administration, Petroleum Supply Annual, DOE/EIA0340 and Petroleum Supply Monthly, DOE/EIA-0109, various issues

- Propane/propylene stocks and product supplied

Energy Information Administration, Petroleum Marketing Annual, DOE/EIA-0487 and Petroleum Marketing Monthly, DOE/EIA-0380, various issues

- Average imported crude oil refiner acquisition costs, propane (consumer-grade) refiner's price of sales to end users

- Energy Information Administration, Winter Fuels Report, DOE/EIA0538, various issues

- Residential propane prices.

\section{Models and Other:}

- Energy Information Administration, Short-Term Integrated Forecasting System

- Forecasts of economic and refinery variables.

\section{Validation, Goodness-of-Fit of Equations Providing Parameter Estimates}

The next table details the parameter estimates and a number of statistics related to the goodness-of-fit of the equations estimated by the PMM. 


\section{REGRESSION RESULTS}

Total U.S. Market

Dependent Variable is PRICE

SAMPLE RANGE: $1989.01-1993.05$

Number of Observations: 53

Convergence achieved after 12 iterations

\begin{tabular}{||c|c|c|c|c||}
\hline VARIABLE & COEFFICIENT & STD. ERROR & T-STAT & Prob>|T| \\
\hline C & 35.105689 & 4.0744392 & 8.6161 & 0.0000 \\
\hline CRUNE & 0.0505421 & 0.3870722 & 0.1306 & 0.8969 \\
\hline CRUDE (-1) & 0.8342886 & 0.3890691 & 2.2728 & 0.0297 \\
\hline HDDSPSQ & 0.0230637 & 0.0478658 & 0.4818 & 0.6331 \\
\hline HDDSPSQ(-1) & 0.1566631 & 0.0565233 & 2.7717 & 0.0091 \\
\hline STOCKDIF(-1) & $-3.668 E-05$ & 0.0001399 & -0.2623 & 0.7947 \\
\hline STOCKDIF(-2) & -0.0002949 & 0.0001147 & -2.5700 & 0.0149 \\
\hline JAN & 13.992946 & 2.1322355 & 6.5626 & 0.0000 \\
\hline FEB & 13.980733 & 1.9757258 & 7.0763 & 0.0000 \\
\hline MAR & 11.007546 & 1.9002432 & 5.7927 & 0.0000 \\
\hline APR & 6.1733109 & 1.8462860 & 3.3436 & 0.0021 \\
\hline MAY & 1.9958117 & 1.7360921 & 1.1496 & 0.2586 \\
\hline JUN & -0.6788844 & 1.4855722 & -0.4570 & 0.6507 \\
\hline AUG & 2.6078367 & 1.5583210 & 1.6735 & 0.1037 \\
\hline SEP & 3.1058165 & 1.9188319 & 1.6186 & 0.1151 \\
\hline OCT & 2.9453507 & 2.0903998 & 1.4090 & 0.1682 \\
\hline INOV & 6.4997304 & 2.1778258 & 2.9845 & 0.0053 \\
\hline DEC & 12.127239 & 2.3635989 & 5.1308 & 0.0000 \\
\hline MA(2) & 0.5654844 & 0.1388481 & 4.0727 & 0.0003 \\
\hline AR(1) & 0.4776522 & 0.1166382 & 4.0952 & 0.0003 \\
\hline R-squared & & 0.92816 & Mean of dependent var & 58.2556 \\
\hline Adjusted R-squared & 0.88679 & Sum of squared resid & 211.908 \\
\hline S.E. of regression & 2.53406 & F-statistic & 22.4382 \\
\hline Durbin-Watson stat & 1.74061 & Prob(F-statistic) & 0.00000 \\
\hline & & & & \\
\hline & & & & \\
\hline
\end{tabular}


Dependent Variable is DEMAND

SAMPLE RANGE: 1989.01 - 1993.05

Number of Observations: 53

\begin{tabular}{|c|c|c|c|c||}
\hline VARIABLE & COEFFICIENT & STD. ERROR & T-STAT & PrOb>|T| \\
\hline C & 812.96815 & 32.047652 & 25.3675 & 0.0000 \\
\hline STOCKDIF(-2) & 0.0054174 & 0.0017907 & 3.0253 & 0.0045 \\
\hline HDD & 30.784476 & 4.9323717 & 6.2413 & 0.0000 \\
\hline DONOV92 & 138.57655 & 75.648570 & 1.8318 & 0.0750 \\
\hline DODEC92 & 209.80561 & .75 .528859 & 2.7778 & 0.0085 \\
\hline JAN & 515.09537 & 45.920129 & 11.2172 & 0.0000 \\
\hline FEB & 439.46719 & 43.103537 & 10.1956 & 0.0000 \\
\hline MAR & 266.36025 & 42.874757 & 6.2125 & 0.0000 \\
\hline APR & 68.205195 & 42.431812 & 1.6074 & 0.1165 \\
\hline MAY & -18.904094 & 42.475149 & -0.4451 & 0.6589 \\
\hline JUN & -70.408909 & 44.722913 & -1.5743 & 0.1239 \\
\hline AUG & 57.971231 & 44.727338 & 1.2961 & 0.2030 \\
\hline SEP & 135.02976 & 44.724093 & 3.0192 & 0.0046 \\
\hline OCT & 253.28219 & 44.758127 & 5.6589 & 0.0000 \\
\hline NOV & 268.33701 & 48.627089 & 5.5183 & 0.0000 \\
\hline DEC & 401.59385 & 49.104785 & 8.1783 & 0.0000 \\
\hline R-squared & & 0.93019 & Mean of dependent var & 985.830 \\
\hline Adjusted R-squared & 0.90189 & Sum of squared resid & 148008. \\
\hline S.E. of regression & 63.2473 & F-statistic & 32.8668 \\
\hline Durbin-Watson & stat & 1.87089 & Prob(F-statistic) & 0.00000 \\
\hline & & & & \\
\hline
\end{tabular}




\section{REGRESSION RESULTS \\ PAD District I}

Dependent Variable is DEMAND1

SAMPLE RANGE: 1989.01 - 1993.05

Number of Observations: 53

\begin{tabular}{|c|c|c|c|c||}
\hline VARIABLE & COEFFICIENT & STD. ERROR & T-STAT & PrOb $|T|$ \\
\hline C & 125.85009 & 5.6615382 & 22.2290 & 0.0000 \\
\hline HDD1 & 6.9747733 & 0.7138366 & 9.7708 & 0.0000 \\
\hline DONOV92 & 8.5687056 & 13.083805 & 0.6549 & 0.5165 \\
\hline DODEC92 & 38.097082 & 13.115489 & 2.9047 & 0.0061 \\
\hline JAN & 135.55630 & 8.1683493 & 16.5953 & 0.0000 \\
\hline FEB & 109.98476 & 7.7742387 & 14.1473 & 0.0000 \\
\hline MAR & 57.990841 & 7.6066964 & 7.6237 & 0.0000 \\
\hline APR & 2.8277032 & 7.6010201 & 0.3720 & 0.7119 \\
\hline MAY & -12.720721 & 7.5993039 & -1.6739 & 0.1024 \\
\hline JUN & -16.189252 & 8.0066579 & -2.0220 & 0.0503 \\
\hline AUG & 14.155164 & 8.0066006 & 1.7679 & 0.0851 \\
\hline SEP & 24.153045 & 8.0070639 & 3.0165 & 0.0045 \\
\hline OCT & 46.651384 & 8.0074618 & 5.8260 & 0.0000 \\
\hline NOV & 48.856692 & 8.6510148 & 5.6475 & 0.0000 \\
\hline DEC & 97.982574 & 8.6633430 & 11.3100 & 0.0000 \\
\hline R-squared & & 0.95909 & Mean of dependent var & 166.309 \\
\hline Adjusted R-squared & 0.94401 & Sum of squared resid & 4872.02 \\
\hline S.E. Of regression & 11.3230 & F-statistic & 63.6256 \\
\hline Durbin-Watson stat & 1.80266 & Prob (F-statistic) & 0.00000 \\
\hline
\end{tabular}




\section{REGRESSION RESULTS}

PAD District II

Dependent Variable is DEMAND2

SAMPLE RANGE: 1989.01 - 1993.04

Number of Observations: 52

\begin{tabular}{|c|c|c|c|c||}
\hline VARIABLE & COEFFICIENT & STD. ERROR & T-STAT & Prob>|T| \\
\hline C & 266.29286 & 42.023750 & 6.3367 & 0.0000 \\
\hline HDD2 & 9.2404841 & 1.5095011 & 6.1215 & 0.0000 \\
\hline PRICE2 & -1.5127742 & 0.7302314 & -2.0716 & 0.0455 \\
\hline DONOV92 & 158.97165 & 34.935537 & 4.5504 & 0.0001 \\
\hline DODEC92 & 133.84972 & 35.079771 & 3.8156 & 0.0005 \\
\hline JAN & 300.42466 & 23.729096 & 12.6606 & 0.0000 \\
\hline FEB & 243.16349 & 21.634953 & 11.2394 & 0.0000 \\
\hline MAR & 140.60105 & 20.882076 & 6.7331 & 0.0000 \\
\hline APR & 23.711039 & 20.598186 & 1.1511 & 0.2573 \\
\hline MAY & -9.8991194 & 20.905625 & -0.4735 & 0.6387 \\
\hline JUN & -12.562579 & 20.869736 & -0.6020 & 0.5510 \\
\hline AUG & 50.068838 & 20.895836 & 2.3961 & 0.0219 \\
\hline SEP & 88.179150 & 20.924472 & 4.2142 & 0.0002 \\
\hline OCT & 178.65841 & 20.969536 & 8.5199 & 0.0000 \\
\hline NOV & 154.97171 & 23.442471 & 6.6107 & 0.0000 \\
\hline DEC & 228.61644 & 25.256732 & 9.0517 & 0.0000 \\
\hline R-squared & & 0.94643 & Mean of dependent var & 296.885 \\
\hline Adjusted R-squared & 0.92411 & Sum of squared resid & 31335.2 \\
\hline S.E. of regression & 299.5029 & F-statistic & 42.4014 \\
\hline Durbin-Watson stat & 1.52868 & Prob F-statistic) & 0.00000 \\
\hline & & & & \\
\hline & & & & \\
\hline
\end{tabular}


Dependent Variable is PRICE2

SAMPLE RANGE: 1989.01 - 1993.04

Number of Observations: 51

Convergence achieved after 5 iterations

\begin{tabular}{|c|c|c|c|c|c|}
\hline VARIABLE & \multicolumn{2}{|c|}{ COEFFICIENT } & STD. ERROR & T-STAT & Prob $>|\mathrm{T}|$ \\
\hline $\mathrm{C}$ & \multicolumn{2}{|c|}{44.693625} & 6.7456910 & 6.6255 & 0.0000 \\
\hline $\operatorname{STKDIF2}(-2)$ & \multicolumn{2}{|c|}{-0.0002792} & 0.0002276 & -1.2267 & 0.2286 \\
\hline HDDSPSQ2 $(-1)$ & \multicolumn{2}{|c|}{0.1237428} & 0.0143155 & 8.6440 & 0.0000 \\
\hline CRUDE & \multicolumn{2}{|c|}{1.2415074} & 0.2361146 & 5.2581 & 0.0000 \\
\hline $\operatorname{PRICE} 2(-12)$ & \multicolumn{2}{|c|}{-0.1376497} & 0.0686892 & -2.0040 & 0.0533 \\
\hline JAN & \multicolumn{2}{|c|}{16.462349} & 2.2834532 & 7.2094 & 0.0000 \\
\hline FEB & \multicolumn{2}{|c|}{14.754723} & 1.9942275 & 7.3987 & 0.0000 \\
\hline MAR & \multicolumn{2}{|c|}{10.097754} & 1.8480355 & 5.4640 & 0.0000 \\
\hline APR & \multicolumn{2}{|c|}{8.0729644} & 1.6721608 & 4.8279 & 0.0000 \\
\hline MAY & \multicolumn{2}{|c|}{2.6619221} & 1.4046996 & 1.8950 & 0.0669 \\
\hline JUN & \multicolumn{2}{|c|}{-0.5510460} & 1.0439594 & -0.5278 & 0.6011 \\
\hline AUG & \multicolumn{2}{|c|}{-0.3606424} & 1.0970808 & -0.3287 & 0.7444 \\
\hline SEP & \multicolumn{2}{|c|}{-1.2874428} & 1.5511660 & -0.8300 & 0.4125 \\
\hline OCT & \multicolumn{2}{|c|}{-2.3011433} & 1.8292416 & -1.2580 & 0.2172 \\
\hline NOV & \multicolumn{2}{|c|}{2.7084960} & 1.9251698 & 1.4069 & 0.1688 \\
\hline $\mathrm{DEC}$ & \multicolumn{2}{|c|}{9.8219131} & 1.9944100 & 4.9247 & 0.0000 \\
\hline $\mathrm{AR}(1)$ & \multicolumn{2}{|c|}{0.9076276} & 0.0870725 & 10.4238 & 0.0000 \\
\hline $\operatorname{MA}(2)$ & \multicolumn{2}{|c|}{-0.7576949} & 0.1302063 & -5.8192 & 0.0000 \\
\hline \multicolumn{2}{|l|}{ R-squared } & 0.95927 & \multicolumn{2}{|c|}{ Mean of dependent var } & 60.1629 \\
\hline \multicolumn{2}{|c|}{ Adjusted R-squared } & 0.93828 & \multicolumn{2}{|c|}{ Sum of squared resid } & 140.727 \\
\hline \multicolumn{2}{|c|}{ S.E. of regression } & 2.06505 & \multicolumn{2}{|c|}{ F-statistic } & 45.7156 \\
\hline \multicolumn{2}{|c|}{ Durbin-Watson stat } & 2.06118 & \multicolumn{2}{|c|}{ Prob (F-statistic) } & 0.00000 \\
\hline
\end{tabular}




\section{BIBLIOGRAPHY}

M. Burdette, J. Cook, D. Hinton, \& J. Zyren, "Midwest Propane Markets, 1992-1993: A Mid-Season Assessment," Winter Fuels Report: DOE/EIA0538(92/93-18), February 1993, pp. xi-xvii.

Energy Information Administration, Short-Term Integrated Forecasting System, 1993 Model Documentation Report, DOE/EIA-M041(93), 1993, Washington, DC.

Energy Information Administration, An Analysis of Heating Fuel Market Behavior in 1989-90, Service Report, SR/OG/90-01, 1990, Washington, DC.

P. Kennedy, A Guide To Econometrics, 2nd Edition, MIT Press, Cambridge, Massachusetts, 1985. 


\section{Model Abstract}

Model Name: Propane Market Model

Model Acronym: PMM

Model Description: The PMM performs a short-term (6- to 9-month) forecast of demand and price in the residential U.S. propane market; the model also calculates the end-of-month stock level. The model can also be used to calculate the demand and end-of-month stock level in several PAD districts. The model is used to analyze certain market behavior assumptions or market shocks and to determine their effect on market price, demand, and stocks.

Last Model Update: October, 1993.

Part of Another Model: None.

Model Interfaces: None. The PMM uses inputs from STIFS, from which it obtains Economic and Refinery Data.

\section{Sponsor:}

- Office: Office of Oil and Gas

- Division: Petroleum Marketing Division

- Branch: Publications and Analysis, EI-432

- Model Contact: Charles Dale

- Telephone: (202) 586-1805.

Documentation: Energy Information Administration, Model Documentation of the Propane Market Model, DOE/EIA-M055, (Washington, DC, October, 1993).

Archive Media and Installation Guides: Archived on micro-floppy disks, with internal documentation. Available from sponsoring office. Archive packages describing the use of the model in published applications may be obtained from:

National Technical Information Service 5285 Port Royal Road 
Springfield, Virginia 22161

Purpose: The Propane Market Model was developed to provide support for the annual "Propane Outlook" article published in the Petroleum Marketing Monthly. The PMM assesses the market response to alternative market scenarios and/or shocks. The model uses the STIFS mid-world oil price case for values of economic and refinery behavior variables to assist in defining a base-line case and then uses assumptions on different possible market disturbances to assess their effects on a monthly basis. The PMM provides a framework to calculate stock levels from the estimated demand and price variables.

Energy System Described by Model: The residential propane demand, enduser prices, and end-of-month stock levels.

\section{Coverage:}

Geographic: National, PAD districts 1 and 2

Time Unit/Frequency: Monthly

Products: Consumer-grade propane

Economic Sector: Residential propane market.

\section{Modeling Features:}

Model Structure: Multi-equation model

Modeling Technique: Ordinary least squares, with correction for autocorrelation

Special Features: None.

\section{NOn-DOE Input Sources:}

Data Resources, Inc. (DRI) database, data from the Bureau of Labor statistics

- Producer price index data

U.S. Department of Commerce, National Oceanographic and Atmospheric Administration, Data Source DRD $964 \mathrm{X}$

Actual and normal statewide monthly heating degree day values. 
DOE Data Input Sources:

Forms and Publications:

Energy Information Administration, Petroleum Supply Annual, DOE/EIA-0340 and Petroleum Supply Monthly, DOE/EIA-0109

- Propane/propylene stocks and product supplied

Energy Information Administration, Petroleum Marketing Annual, DOE/EIA-0487 and Petroleum Marketing Monthly, DOE/EIA-0380

- Average imported crude oil refiner acquisition costs, refiner price of propane (consumer-grade) sales to end users

Energy Information Administration, Winter Fuels Report, DOE/EIA0538, various issues

- Residential propane prices.

Models and Other:

Energy Information Administration, Short-Term Integrated Forecasting System

- Forecasts of economic and refinery variables.

General Output Descriptions: PMM is used to generate very short-term (up to 9 months), monthly forecasts of U.S. demand, price, and stock levels of residential (consumer-grade) propane. There is also provision for demand forecasts in certain PAD districts.

Computing Environment:

- Hardware Used: IBM-compatible personal computer

- Operating System: MS DOS

- Software Used: Micro-TSP, Version 7.01 or higher

- Memory Requirements: $640 \mathrm{~K}$

- Storage Requirements: $640 \mathrm{~K}$

- Estimated Run Time: 30 seconds calculation time on an 80386 PC operating under DOS 5

- Special Features: None 
Independent Expert Reviews: None.

Status of Evaluations by Sponsor: on-going.

\section{References}

M. Burdette, J. Conk, D. Hinton, \& J. Zyren, "Midwest Propane Markets, 1992-1993: A Mid-Season Assessment," Winter Fuels Report, DOE/EIA0538(92/93-18), February 1993, pp. xi-xvii.

Energy Information Administration, Short-Term Integrated Eorecasting System, 1993 Model Documentation Report, DOE/EIA-M041(93), 1993, Washington, DC.

Energy Information Administration, An Analysis of Heating Fuel Market Behavior in 1989-90, Service Report, SR/OG/90-01, 1990, Washington, DC.

P. Kennedy, A Guide To Econometrics, 2nd Edition, MIT Press, Cambridge, Massachusetts, 1985. 


\section{Model Cross Reference}

Total U.S. Market

Bquations

(Pages 6-8)

DEMAND

PRICE

DELSTOCK

STOCK

STOCKNIF

RETPRICE

RESPRICE

Variable Name

PRICE

CRUDE

DEMAND

HDD

HDDSPSQ

PPI

DUMMY

DONOV92

DODEC 92

DELSTOCK

STOCK

PRIM_SUP

DAYS

STOCKDIF
Name in Code

PRICE

CRUDE

DEMAND

HDD

HDDSPSQ

PPI

JAN, FEB, etc.

DONOV92

DODEC92

DELSTOCK

STOCK

PRIM_SUP

DAYS

STOCKDIF
Location in code (Line Numbers)

$1-3$

$7-11$

4

5

6

12

13

\section{Iecation in code}

7,12

7

1,4

1

7,8

12

$2-3,8-10$

1

2

4,5

5,6

4

4

$1,6,8$ 


\section{Model Cross Reference}

Total U.S. Market

(continued)

Variable Name

STOCKAVG

RESPRICE

$\gamma$

RETPRICE
Name in Code

STOCKAVG

RESPRICE

GAMMA

RETPRICE
Location in Code

6

13

13

12,13 
Equations

(Paces 11-12)

DEMAND1

DELSTK1

STOCK1

Variable Name

DEMAND1

HDD1

DUMMY

DONOV92

DODEC92

DELSTK1

STOCK1

PRIMSUP1

DAYS
Name in Code

DEMAND1

HDD1

JAN, FEB, etc.

DONOV92

DODEC92

DELSTK1

STOCK1

PRIMSUP1

DAYS
Location in Code

(Line numberg)

$$
1-3
$$

4

5

Location in code

1,4

1

$1-3$

1

2

4,5

5

4

4 


\section{Model Cross Reference}

\section{PAD District II}

\section{Equations \\ (Pages 11-12)}

DEMAND2

PRICE2
DELSTK2
STOCK2
STKDIF2
Variable Name

PRICE2

CRUDE

DEMAND2

HDD2

HDDSPSQ2

DUMMY

DONOV92

DODEC92

DELSTK2

STOCK2

PRIMSUP2

DAYS

STOCKDIF

STKAVG2
Name in Code

PRICE2

CRUDE

DEMAND2

HDD2

HDDSPSQ2

JAN, FEB, etc.

DONOV92

DODEC9

DELSTK2

STOCK2

PRIMSUP2

DAYS

STOCKDIF

STKAVG2
Location in Code

(Line Numbers)

$1-4$

$5-7$

8

9

10

Location in code

$1,2,5$

1

5,8

5

1

$2-4,6-7$

5

5

8,9

9,10

8

8

1,10

10 

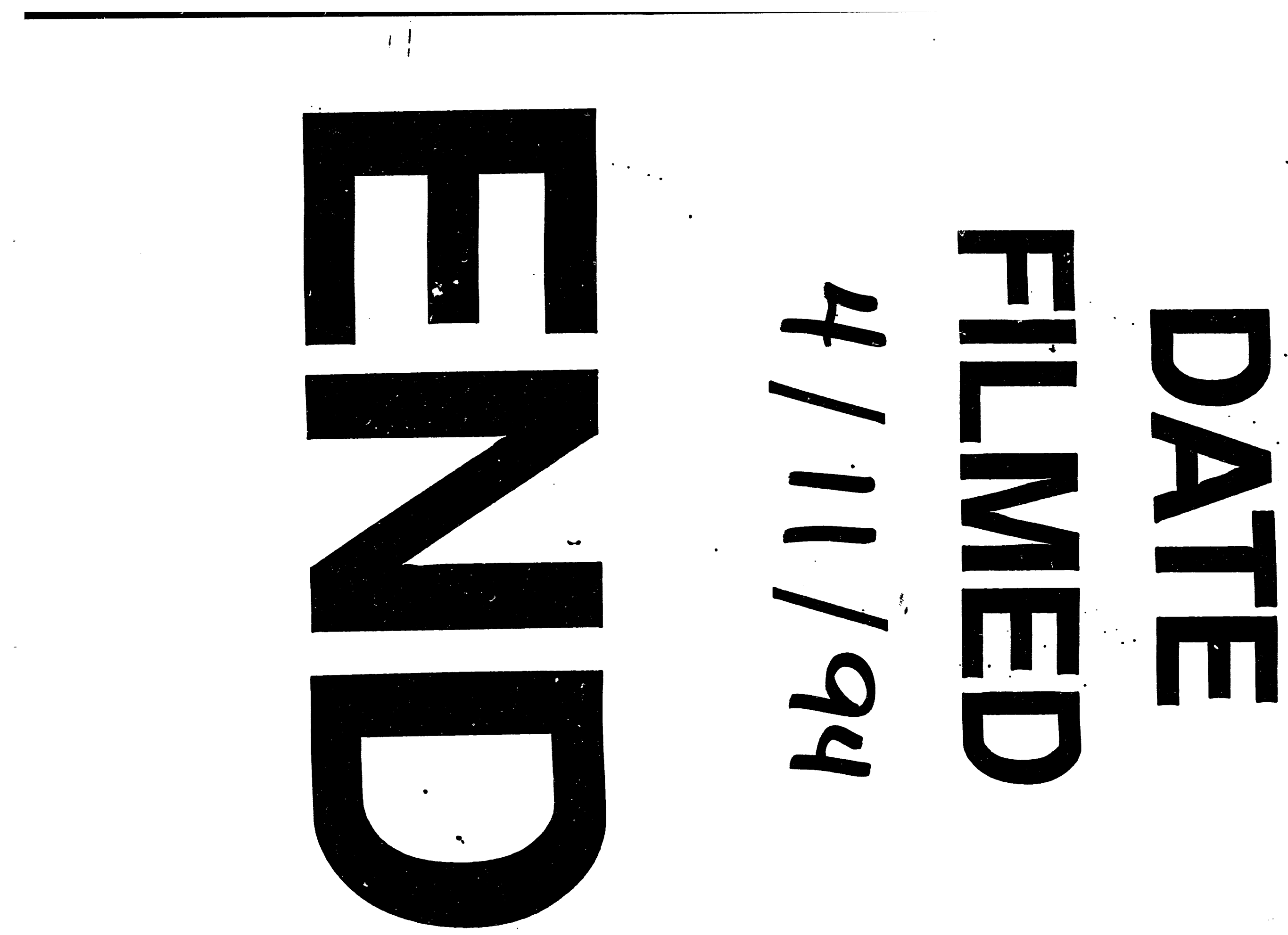
